\title{
Jannaschia rubra sp. nov., a red-pigmented bacterium isolated from sea water
}

\author{
Correspondence \\ M. J. Pujalte \\ maria.j.pujalte@uv.es
}

\author{
M. C. Macián, ${ }^{1,2}$ D. R. Arahal, ${ }^{2,3}$ E. Garay, ${ }^{1,2,3}$ W. Ludwig, ${ }^{4}$ K. H. Schleifer ${ }^{4}$ \\ and M. J. Pujalte ${ }^{1,2}$ \\ ${ }^{1}$ Instituto Cavanilles de Biodiversidad y Biología Evolutiva, Universitat de València, València, \\ Spain \\ ${ }^{2,3}$ Departamento de Microbiología y Ecología ${ }^{2}$ and Colección Española de Cultivos Tipo \\ $(\mathrm{CECT})^{3}$, Facultad de Biología, Universitat de València, Campus de Burjassot, 46100 \\ València, Spain \\ ${ }^{4}$ Lehrstuhl für Mikrobiologie, Technische Universität München, Am Hochanger 4, D-85350 \\ Freising, Germany
}

\begin{abstract}
A Gram-negative, slightly halophilic, strictly aerobic, chemo-organotrophic bacterium was isolated from Mediterranean sea water near Valencia (Spain). Comparison of the almost complete 16S rRNA gene sequence showed that strain $4 \mathrm{SM}^{\top}$ belonged to the Roseobacter group, with Jannaschia helgolandensis as its closest relative, with a similarity of $98 \cdot 7 \%$. DNA-DNA hybridization analysis showed that the Mediterranean isolate had a level of relatedness of less than $42 \%$ with $\mathrm{J}$. helgolandensis and therefore that it represented a novel species of the genus Jannaschia. Phenotypic characteristics gave further evidence that the two organisms are not related at the species level. Isolate $4 \mathrm{SM}^{\top}$ grows on solid media as irregular pink-red colonies that penetrate into the agar. Cells are rods, motile by a tuft of polar flagella. The DNA base composition is $64.6 \mathrm{~mol} \% \mathrm{G}+\mathrm{C}$. Morphological, physiological and genotypic differences from related species support the description of a novel species, Jannaschia rubra sp. nov., with strain $4 \mathrm{SM}^{\top}\left(=\right.$ CECT $\left.5088^{\top}=\mathrm{DSM} 16279^{\mathrm{T}}\right)$ as the type strain.
\end{abstract}

The genus Jannaschia was described by Wagner-Döbler et al. (2003) to accommodate two strains isolated from sea water sampled in the North Sea, with Jannaschia helgolandensis as the type and sole species. The genus was defined based on its phenotypic characteristics, including unique chemotaxonomic features, and its isolated position on the phylogenetic branch of Roseobacter and related genera in the $\alpha$-Proteobacteria. A second species, Jannaschia cystaugens, has been proposed by Adachi et al. (2004) that includes marine isolates from the Seto inland sea in Japan. A third species of the genus is proposed here to accommodate a strain obtained from Mediterranean sea water sampled on the Spanish east coast, near Valencia.

Strain $4 \mathrm{SM}^{\mathrm{T}}$ was isolated after direct plating of sea water dilutions on marine agar (MA; Scharlab) and incubation at

Published online ahead of print on 8 October 2004 as DOI 10.1099/ ijs.0.63412-0.

Abbreviation: $\mathrm{PHB}$, poly- $\beta$-hydroxybutyrate.

The GenBank/EMBL/DDBJ accession number for the 16S rRNA gene sequence of Jannaschia rubra $4 \mathrm{SM}^{\top}{ }^{\top}$ is AJ748747.

Transmission and scanning electron micrographs of cells of strain $4 \mathrm{SM}^{\top}$ are available as supplementary material in IJSEM Online.
$25{ }^{\circ} \mathrm{C}$ for 10 days. The sampling area was $3 \cdot 2-4 \cdot 8 \mathrm{~km}$ off the coast. Samples were taken by a diver with sterile bottles at 15-20 m water depth and transported under refrigeration to the laboratory within 3-4 h. The sample from which strain $4 \mathrm{SM}^{\mathrm{T}}$ was isolated was obtained in April 1990. The strain was phenotypically characterized and could not be ascribed to any recognized taxon in a previous numerical taxonomic study (phenon 45 in Ortigosa et al., 1994).

Since then, the strain has been maintained at $-80{ }^{\circ} \mathrm{C}$, with cells suspended in marine broth (MB; Scharlab) plus $10 \%$ glycerol, and also by lyophilization. Working strains were routinely cultured on $\mathrm{MA}$ and $\mathrm{MB}$ at $20-25^{\circ} \mathrm{C}$. Most methods for biochemical characterization used here were performed as previously described by Ortigosa et al. (1994) and Macián et al. (2001), except for Tween 80 and DNase tests, which were performed in media prepared with halfstrength artificial sea water (ASW: $400 \mathrm{mM} \mathrm{NaCl}, 100 \mathrm{mM}$ $\mathrm{MgSO}_{4} \cdot 7 \mathrm{H}_{2} \mathrm{O}, 20 \mathrm{mM} \mathrm{KCl}$ and $\left.20 \mathrm{mM} \quad \mathrm{CaCl}_{2} \cdot \mathrm{H}_{2} \mathrm{O}\right)$ (Baumann \& Baumann, 1981), and sulfite oxidation, which was tested according with González et al. (1999). Bacteria grown on MA for 2-3 days were used for scanning electron microscopy. A cell suspension was prepared with half-strength ASW and adsorbed onto Isopore membrane filters. Filters were dehydrated with a graded series of 
ethanol (50, 80 and $100 \%$ ethanol), critical-point dried with $\mathrm{CO}_{2}$ (Autosamdri-814) and sputter-coated with a goldpalladium film to a thickness of about $10 \mathrm{~nm}$ (Bio-Rad sputter coater). Samples were examined in a Hitachi S-4100 field emission scanning electron microscope with $7-15 \mathrm{~mm}$ working distance and at an acceleration voltage of $10 \mathrm{kV}$. Pictures were stored digitally and processed using EMIP 3.0. In parallel, samples were examined in a JEOL JEM-1010 transmission electron microscope at $60 \mathrm{kV}$ after negative staining with $2 \%(\mathrm{w} / \mathrm{v})$ phosphotungstic acid at appropriate $\mathrm{pH}$.

Cells are rod-shaped and motile in young cultures as observed by optical microscopy. Up to five monopolar flagella could be seen by transmission electron microscopy (Supplementary Fig. C in IJSEM Online). Binary division was observed on scanning electron micrographs (Supplementary Fig. $\mathrm{H}$ in IJSEM Online). Rosette formation was not observed, but cells tended to form tight aggregates. Bright granules were never seen on wet mounts of cells of different ages and grown under different culture conditions, suggesting that strain $4 \mathrm{SM}^{\mathrm{T}}$ does not accumulate poly- $\beta$ hydroxybutyrate (PHB).

Colonies on MA are initially whitish but they progressively develop a dark-red pigmentation as the cultures age and become more dense. Young (less than 6 days old) colonies are smooth and shiny and have a regular border, but they become rough with increasing pigmentation and penetrate into the agar, being difficult to remove and to disperse into aqueous solutions.

The organism is unable to ferment sugars under anaerobic conditions as determined on anaerobic Hugh \& Leifson $\mathrm{O} / \mathrm{F}$ medium with half-strength ASW. It does not reduce nitrate to nitrite in nitrate broth and it is unable to grow in denitrification medium of Baumann \& Baumann (1981). Strain $4 \mathrm{SM}^{\mathrm{T}}$ showed a quick and clear positive response to the test for the presence of cytochrome oxidase, whereas $J$. helgolandensis has been described to give a weakly positive reaction (Wagner-Döbler et al., 2003). In our laboratory we have confirmed that its response is much slower and less intense than that of strain $4 \mathrm{SM} 3^{\mathrm{T}}$.

The range of salinities that support growth of strain $4 \mathrm{SM}^{\mathrm{T}}$ was tested in MA [which contains approximately $2 \%(\mathrm{w} / \mathrm{v})$ $\mathrm{NaCl}$ and $1.4 \%(\mathrm{w} / \mathrm{v})$ other salts]. The upper limit was resolved by adding increasing amounts of $\mathrm{NaCl}$ up to 6 , $7,8,9$ and $10 \%(w / v)$ total salinity. Growth and pigmentation were observed in media containing up to $8 \%(\mathrm{w} / \mathrm{v})$ total salinity, after 7 days of incubation. In MA with $9 \%$ $(\mathrm{w} / \mathrm{v})$ total salts, growth was observed only after 12 days and no pigment was produced. Strain $4 \mathrm{SM}^{\mathrm{T}}$ was unable to grow at $10 \%(\mathrm{w} / \mathrm{v})$ salinity. Thus, our isolate could be regarded as slightly halophilic. J. helgolandensis DSM $14858^{\mathrm{T}}$ was included in the experiments, and we found that this strain was able to grow at up to $7 \%(\mathrm{w} / \mathrm{v})$ but not at higher salinity.
In order to determine the minimal amount of salts required for growth, MA was diluted with distilled water to produce media containing $0.34,0.68,1.02,1.36$ and $1.7 \%(\mathrm{w} / \mathrm{v})$ total salts (dilution factors of $0 \cdot 1,0 \cdot 2,0 \cdot 3,0 \cdot 4$ and $0 \cdot 5$, respectively). The loss of nutrients and agar by dilution was compensated for by adding the appropriate amounts of peptone, yeast extract and agar. Growth diminished progressively with decreasing salinity down to $0 \cdot 34 \%(\mathrm{w} / \mathrm{v})$ salts. Pigmentation was observed even with $1.02 \%(\mathrm{w} / \mathrm{v})$ salts, but was not present at lower concentrations. J. helgolandensis DSM $14858^{\mathrm{T}}$ was able to grow with 0.68 but not with $0 \cdot 34 \%(\mathrm{w} / \mathrm{v})$ salts.

Ionic requirements were determined in salt tolerance agar (STA) containing $1 \%(\mathrm{w} / \mathrm{v})$ tryptone, $0.3 \%(\mathrm{w} / \mathrm{v})$ yeast extract and $1.5 \%(\mathrm{w} / \mathrm{v})$ agar with different combinations of salts: (i) STA with $2 \%(\mathrm{w} / \mathrm{v}) \mathrm{NaCl}$, (ii) STA with $2 \%$ (w/v) $\mathrm{NaCl}$ and $0 \cdot 2 \%(\mathrm{w} / \mathrm{v}) \mathrm{CaCl}_{2} \cdot 2 \mathrm{H}_{2} \mathrm{O}$, (iii) STA with $2 \%$ (w/v) $\mathrm{NaCl}$ and $0.9 \%(\mathrm{w} / \mathrm{v}) \mathrm{MgCl}_{2} \cdot 6 \mathrm{H}_{2} \mathrm{O}$ and (iv) STA with $2 \%$ (w/v) $\mathrm{NaCl}, 0.9 \%$ (w/v) $\mathrm{MgCl}_{2} \cdot 6 \mathrm{H}_{2} \mathrm{O}, 0.2 \%$ (w/v) $\mathrm{CaCl}_{2} \cdot 2 \mathrm{H}_{2} \mathrm{O}$ and $0.06 \%(\mathrm{w} / \mathrm{v}) \mathrm{KCl}$ (all concentrations are equal to those found in $\mathrm{MB}$ for these four salts). Strain $4 \mathrm{SM}^{\mathrm{T}}{ }^{\mathrm{T}}$, as well as J. helgolandensis DSM $14858^{\mathrm{T}}$, was unable to grow after 7 days of incubation at $25^{\circ} \mathrm{C}$ in STA with just $\mathrm{NaCl}$ or with $\mathrm{NaCl}$ plus $\mathrm{CaCl}_{2} \cdot 2 \mathrm{H}_{2} \mathrm{O}$, indicating that $\mathrm{Na}^{+}$and $\mathrm{Ca}^{2+}$ ions together do not meet the salt requirements for growth of these organisms. Good growth was observed for both strains with the combination of $\mathrm{NaCl}$ and $\mathrm{MgCl}_{2} \cdot 6 \mathrm{H}_{2} \mathrm{O}$, suggesting that $\mathrm{Na}^{+}$and $\mathrm{Mg}^{2+}$ ions are required. However, under these conditions, pigmentation was delayed in the case of strain $4 \mathrm{SM}^{\mathrm{T}}$.

Growth at different temperatures was tested in both liquid (MB) and solid (MA) media at 4, 15, 25, 37 and $40{ }^{\circ} \mathrm{C}$. Nutritional screening was carried out on basal medium agar (BMA), which contained $50 \mathrm{mM}$ Tris/HCl $\left(\mathrm{pH} \mathrm{7.5)}, \quad 19 \mathrm{mM} \quad \mathrm{NH}_{4} \mathrm{Cl}, \quad 0.33 \mathrm{mM} \quad \mathrm{K}_{2} \mathrm{HPO}_{4} .3 \mathrm{H}_{2} \mathrm{O}\right.$, $0.1 \mathrm{mM} \mathrm{FeSO} \mathrm{O}_{4} .7 \mathrm{H}_{2} \mathrm{O}$ and $1.3 \%$ (w/v) purified agar (Oxoid) on half-strength ASW (Baumann \& Baumann, 1981). Carbohydrates were added at $2 \mathrm{~g} \mathrm{l}^{-1}$ and the remaining compounds were added at $1 \mathrm{~g} \mathrm{l}^{-1}$. BMA was supplemented with $0 \cdot 1 \mathrm{~g}$ yeast extract $1^{-1}$ because the organism was originally reported to be unable to grow on minimal medium (Ortigosa et al., 1994), and incubation was prolonged until 14 days. Positive control plates were prepared with $5 \mathrm{~g}$ yeast extract $\mathrm{l}^{-1}$ and negative control plates consisted of BMA plus $0 \cdot 1$ g yeast extract $l^{-1}$. Growth was scored as negative when growth was equal to or less than that in the negative control plates. It was noted that, for some carbon sources that supported growth, pigmentation was absent or delayed. The results are summarized in Table 1 and in the species description below.

The cellular fatty acid composition, determined by GLC at the DSMZ using a method described by Kämpfer \& Kroppenstedt (1996), included $18: 1 \omega 7 c$ as the major fatty acid $(79 \cdot 4 \%)$, a characteristic common to all genera in the Roseobacter group. The second most abundant fatty acid in strain $4 \mathrm{SM} 3^{\mathrm{T}}$ was $18: 0(8 \cdot 13 \%)$, followed by cyclo $19: 0 \omega 8 \mathrm{c}$ 
Table 1. Phenotypic characteristics that differentiate Jannaschia rubra sp. nov. from J. helgolandensis and J. cystaugens

+ , Positive; -, negative; (+), weakly positive; ND, not determined. Data are from this study unless indicated.

\begin{tabular}{|c|c|c|c|}
\hline Characteristic & J. rubra & J. helgolandensis & J. cystaugens ${ }^{*}$ \\
\hline Oxidase & + & $(+) \dagger$ & + \\
\hline Pigmentation & Red & None $\dagger$ & Brown \\
\hline Motility & + & $-\dagger$ & + \\
\hline Cell shape & Rods & Irregular rods $\dagger$ & Irregular rods \\
\hline White inclusions & - & $+\dagger$ & + \\
\hline DNase & + & - & ND \\
\hline $\begin{array}{l}\text { Salinity range for } \\
\text { growth }(\%)\end{array}$ & $0 \cdot 34-9$ & $0 \cdot 68-8$ & $2-7$ \\
\hline \multicolumn{4}{|l|}{ Utilization of: } \\
\hline Rhamnose & - & + & - \\
\hline Maltose & $(+)$ & - & - \\
\hline Cellobiose & - & + & - \\
\hline meso-Inositol & $(+)$ & - & - \\
\hline Arginine & $(+)$ & - & ND \\
\hline Citrulline & $+\ddagger$ & - & ND \\
\hline L-Histidine & $(+)$ & - & ND \\
\hline Sarcosine & + & - & $\mathrm{ND}$ \\
\hline Putrescine & + & - & ND \\
\hline \multicolumn{4}{|l|}{ Fatty acids: } \\
\hline 19:0 cyclo & + & $+\dagger$ & - \\
\hline $18: 1 \omega 9 c$ & - & $-\dagger$ & + \\
\hline
\end{tabular}

${ }^{*}$ Data from Adachi et al. (2004).

$\dagger$ Data from Wagner-Döbler et al. (2003).

$\ddagger$ Pigment was absent or appeared after 7 days of incubation.

$(5 \cdot 73 \%)$, a cellular fatty acid also present in the type species of the genus Jannaschia. The latter fatty acid was not found by Adachi et al. (2004) in J. cystaugens. Other fatty acids found in strain $4 \mathrm{SM}^{\mathrm{T}}$ are 10:0 $3-\mathrm{OH}(2 \cdot 32 \%), 16: 0$ $(0.68 \%), 20: 1 \omega 7 c(0 \cdot 59 \%)$ and three that are unknown: ECL $11.799(2 \cdot 19 \%)$, ECL $15.273(1 \cdot 7 \%)$ and ECL 17.606 $(0 \cdot 7 \%)$.

Bacteriochlorophyll production was determined in acetone extracts using a Beckman DU-600 spectrophotometer as described by Takaichi et al. (1991). Extracts obtained from cells grown in the dark on MA plates and BMA plates containing D-sorbitol as the sole source of carbon and supplemented with $0 \cdot 1 \mathrm{~g}$ yeast extract $l^{-1}$ were analysed and bacteriochlorophyll $a$ was not detected.

The DNA G $+\mathrm{C}$ content was determined by HPLC at DSMZ, following the procedure of Mesbah et al. (1989). Strain $4 \mathrm{SM}^{\mathrm{T}}$ has a $\mathrm{G}+\mathrm{C}$ content of $64 \cdot 6 \mathrm{~mol} \%$. This value is close to those determined for J. helgolandensis and J. cystaugens: $63 \cdot 0$ and $59 \cdot 1 \mathrm{~mol} \%$, respectively (WagnerDöbler et al., 2003; Adachi et al., 2004).

To investigate the genealogy of our isolate, comparative $16 \mathrm{~S}$
rRNA gene sequence analysis was performed. Isolation of genomic DNA, amplification of almost full-length $16 \mathrm{~S}$ rRNA gene fragments and sequencing of the rRNA gene using a LICOR automated sequencer (MWG Biotech) were performed as described by Macián et al. (2001). Sequences were added to the 16S rRNA gene sequence databases of the Technical University Munich using the program package ARB (Ludwig et al., 2004). Automated sequence alignments were inspected by eye and corrected manually using the sequence editor ARB_EDIT. Phylogenetic analyses using different tree-construction methods (maximum-parsimony, maximum-likelihood and distance matrix) and data subsets were performed using the appropriate ARB tools to test the robustness of local topologies (Ludwig et al., 1998). As is commonly observed in such tree comparisons, variations in topology were detected, but none of these occurred among the closest relatives of our isolate. Fig. 1 shows the tree derived by distance matrix analysis, using the Jukes-Cantor correction.

Comparative analyses of the 16S rRNA gene sequence obtained in this study (deposited at the GenBank/EBI database under accession number AJ748747) confirmed the affiliation of strain $4 \mathrm{SM}^{\mathrm{T}}$ to the $\alpha$-Proteobacteria, and more precisely to the genus Jannaschia. The closest 16S rRNA gene sequences were AJ438157, AJ534224 and AJ534225 (Fig. 1), all of which correspond to strains of J. helgolandensis (Wagner-Döbler et al., 2003), bearing $98.7 \%$ sequence similarity with strain $4 \mathrm{SM}^{\mathrm{T}}$. Sequences from other species within the $\alpha$-Proteobacteria, including J. cystaugens, showed similarity levels below $95 \cdot 7 \%$.

DNA-DNA hybridizations were performed between strain $4 \mathrm{SM}^{\mathrm{T}}$ and J. helgolandensis DSM $14858^{\mathrm{T}}$. Experiments were performed using microplates as described by Ziemke et al. (1998). Colour development was measured at $405 \mathrm{~nm}$ using a Wallac Victor V2 plate reader (Perkin-Elmer). Hybridizations were performed at $60^{\circ} \mathrm{C}$. DNA-DNA relatedness between strain $4 \mathrm{SM} 3^{\mathrm{T}}$ and J. helgolandensis DSM $14858^{\mathrm{T}}$ was $42 \%$, a mean value based on two independent hybridization experiments, confirming that the two strains are separated at the species level (Stackebrandt \& Goebel, 1994).

Taking into consideration the distinct phenotypic and genetic properties summarized in Table 1, we conclude that the isolate represents a novel species of the genus Jannaschia. Phenotypic differences that support the consideration of strain $4 \mathrm{SM}^{\mathrm{T}}$ as representing a novel species include its characteristic pigment, its motility and development of flagella, its inability to produce PHB and the salinity range supporting growth (Table 1).

\section{Description of Jannaschia rubra sp. nov.}

Jannaschia rubra (ru'bra. L. fem. adj. rubra red).

Gram-negative, rod-shaped cells, about $1 \cdot 0-2 \cdot 0 \times 0 \cdot 5 \mu \mathrm{m}$. Divides by binary division. Motile by means of three to five monopolar flagella. Growth on MA after 7 days of 


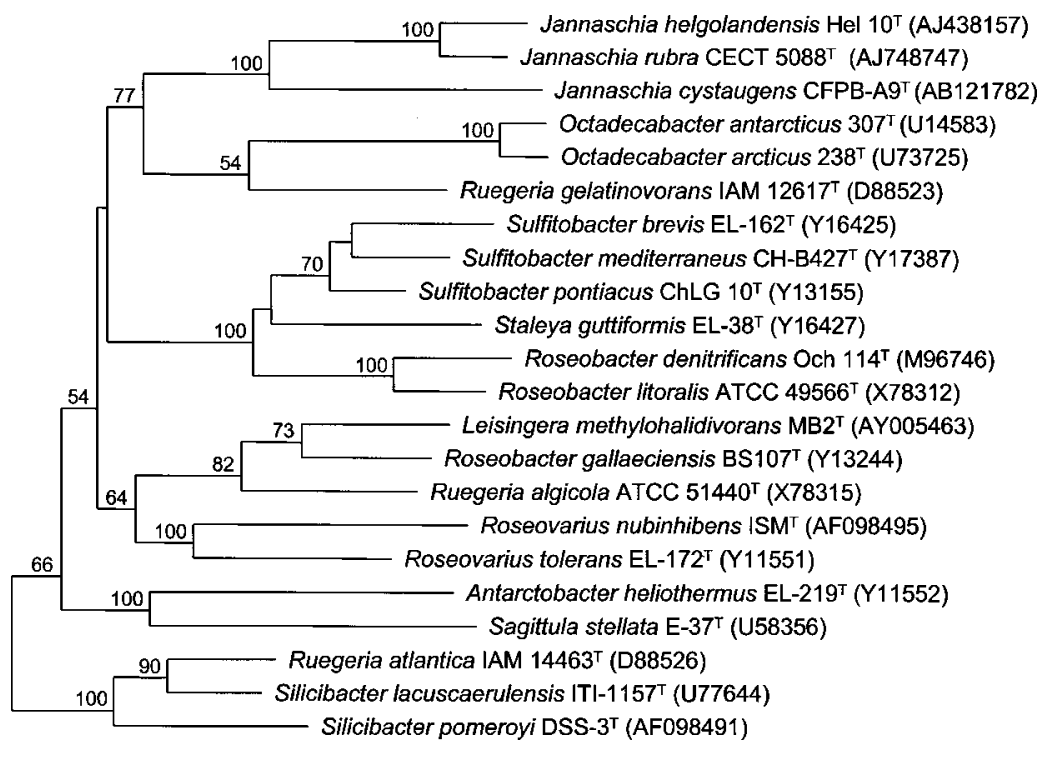

Fig. 1. Phylogenetic relationship based on a distance matrix (Jukes-Cantor correction) of the 16S rRNA gene sequences of Jannaschia rubra sp. nov. and other $\alpha$ Proteobacteria. All sequences are derived from type strains and accession numbers are shown in parentheses. The outgroup (more than 200 bacterial sequences) has been deleted to simplify the figure. Bootstrap values above $50 \%$ are shown at the left of nodes (percentages based on 1000 resamplings). Bar, $5 \%$ sequence divergence.

incubation leads to irregular, red colonies adhering to the agar. It does not swarm or luminesce. Requires at least $0 \cdot 34 \%(\mathrm{w} / \mathrm{v})$ marine salts and tolerates up to $9 \%(\mathrm{w} / \mathrm{v})$ salts. Sodium and magnesium are required. Temperature range for growth is $4-25^{\circ} \mathrm{C}$. No growth detected at $37^{\circ} \mathrm{C}$ or above. Oxidase-positive. Strict aerobic chemo-organotrophic bacterium. Does not reduce nitrate to nitrite or to $\mathrm{N}_{2}$. Does not hydrolyse casein, gelatin, starch, Tween 80 , alginate or lecithin, but shows DNase activity on DNase agar supplemented with half-strength ASW. Negative for arginine dihydrolase, lysine decarboxylase and ornithine decarboxylase activities. Negative for $\mathrm{H}_{2} \mathrm{~S}$ production from thiosulfate, indole production from tryptophan and sulfite oxidation. Able to grow on BMA with the following compounds as carbon and energy sources: D-xylose, Dglucose, D-fructose, D-galactose, D-mannose, glycerol, Dmannitol, D-sorbitol, pyruvate, succinate, fumarate, malate, lactate, acetate, DL- $\beta$-hydroxybutyrate, L-leucine, L-serine, L-glutamate, $\gamma$-aminobutyric acid, L-ornithine, citrulline, L-aspartate, sarcosine and putrescine, provided that the medium is supplemented with a small amount of yeast extract (an indication that undetermined growth factors are required). Under the same conditions, the following carbon sources are weakly positive: maltose, D-gluconate, meso-inositol, glycerate, citrate, cis-aconitate, $\alpha$-ketoglutarate, $\mathrm{L}$-arginine and L-histidine. Pigmentation is absent or delayed when using pyruvate, L-glutamate, $\gamma$-aminobutyric acid, L-ornithine, citrulline, L-aspartate and glycerate. The following substrates are not used: D-ribose, L-arabinose, D-trehalose, L-rhamnose, cellobiose, sucrose, lactose, D-melibiose, amygdalin, D-glucuronate, D-galacturonate, $\mathrm{N}$-acetylglucosamine, saccharate, propionate, $p$-hydroxybenzoate, glycine, L-threonine, L-tyrosine and L-alanine. The $\mathrm{G}+\mathrm{C}$ content of the DNA of strain $4 \mathrm{SM}^{\mathrm{T}}$ is $64 \cdot 6 \mathrm{~mol} \%$.
The type strain, $4 \mathrm{SM}^{\mathrm{T}}\left(=\mathrm{CECT} 5088^{\mathrm{T}}=\mathrm{DSM} 16279^{\mathrm{T}}\right)$, was isolated from Mediterranean sea water.

\section{Acknowledgements}

We are grateful to A. Camacho, Universitat de València, Spain, for bacteriochlorophyll a spectrophotometry. This work was partially supported by the Deutsche Forschungsgemeinschaft and project AGL-2002-04075-C02-C02 of the Spanish Ministerio de Ciencia y Tecnología. D. R. A. has a contract with the Universitat de València under the Ramón y Cajal program (Ministerio de Ciencia y Tecnología).

\section{References}

Adachi, M., Kanno, T., Okamoto, R., Shinozaki, A., FujikawaAdachi, K. \& Nishijima, T. (2004). Jannaschia cystaugens sp. nov., an Alexandrium (Dinophyceae) cyst formation-promoting bacterium from Hiroshima Bay, Japan. Int J Syst Evol Microbiol 54, 1687-1692.

Baumann, P. \& Baumann, L. (1981). The marine Gram-negative eubacteria; genera Photobacterium, Beneckea, Alteromonas, Pseudomonas, and Alcaligenes. In The Prokaryotes, a Handbook on Habitats, Isolation, and Identification of Bacteria, pp. 1302-1330. Edited by M. P. Starr, H. Stolp, H. G. Trüper, A. Balows \& H. G. Schlegel. Berlin: Springer.

González, J. M., Kiene, R. P. \& Moran, M. A. (1999). Transformation of sulfur compounds by an abundant lineage of marine bacteria in the $\alpha$-subclass of the class Proteobacteria. Appl Environ Microbiol 65, $3810-3819$.

Kämpfer, P. \& Kroppenstedt, R. M. (1996). Numerical analysis of fatty acid patterns of coryneform bacteria and related taxa. Can J Microbiol 42, 989-1005.

Ludwig, W., Strunk, O., Klugbauer, S., Klugbauer, N., Weizenegger, M., Neumaier, J., Bachleitner, M. \& Schleifer, K.-H. (1998). Bacterial phylogeny based on comparative sequence analysis. Electrophoresis 19, 554-568. 
Ludwig, W., Strunk, O., Westram, R. \& 29 other authors (2004). ARB: a software environment for sequence data. Nucleic Acids Res 32, 1363-1371.

Macián, M. C., Ludwig, W., Schleifer, K. H., Garay, E. \& Pujalte, M. J. (2001). Thalassomonas viridans gen. nov., sp. nov., a novel marine $\gamma$-proteobacterium. Int J Syst Evol Microbiol 51, 1283-1289.

Mesbah, M., Premachandran, U. \& Whitman, W. B. (1989). Precise measurement of the $\mathrm{G}+\mathrm{C}$ content of deoxyribonucleic acid by high-performance liquid chromatography. Int J Syst Bacteriol 39, 159-167.

Ortigosa, M., Garay, E. \& Pujalte, M. J. (1994). Numerical taxonomy of aerobic, Gram-negative bacteria associated with oysters and surrounding seawater of the Mediterranean coast. Syst Appl Microbiol 17, 589-600.
Stackebrandt, E. \& Goebel, B. M. (1994). Taxonomic note: a place for DNA-DNA reassociation and 16S rRNA sequence analysis in the present species definition in bacteriology. Int J Syst Bacteriol 44, 846-849.

Takaichi, S., Furihata, K., Ishidu, J. \& Shimada, K. (1991). Carotenoid sulphates from the aerobic photosynthetic bacterium, Erythrobacter longus. Phytochemistry 30, 3411-3415.

Wagner-Döbler, I., Rheims, H., Felske, A., Pukall, R. \& Tindall, B. J. (2003). Jannaschia helgolandensis gen. nov., sp. nov., a novel abundant member of the marine Roseobacter clade from the North Sea. Int J Syst Evol Microbiol 53, 731-738.

Ziemke, F., Höfle, M. G., Lalucat, J. \& Rosselló-Mora, R. (1998). Reclassification of Shewanella putrefaciens Owen's genomic group II as Shewanella baltica sp. nov. Int J Syst Bacteriol 48, 179-186. 